\title{
Complications Associated with Colonoscopic Interventions: The 10-Year Experience of a Surgery Clinic
}

\author{
Hacı Hasan Abuoğlu, Mehmet Gençtürk, Emre Günay, Erkan Özkan, \\ Mehmet Onur Gül, Münip Ali Tolga Müftüoğlu
}

Department of General Surgery Haydarpaşa Numune Training and Research Hospital, İstanbul, Turkey

Submitted: 27.07 .2017 Accepted: 28.03.2018

Correspondence: Hacı Hasan Abuoğlu,

Haydarpaşa Numune Eğitim ve Araștırma Hastanesi, Genel Cerrahi Kliniği, İstanbul, Turkey

E-mail:abuoglu@yahoo.com

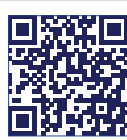

Keywords: Colonic polyps; colonoscopy; hemorrhage; injuries; splenectomy.

\begin{abstract}
Objective: A colonoscopy is a routine procedure used for the diagnosis and treatment of colorectal diseases. The aim of this study was to evaluate complications that occurred related to a colonoscopic examination and the results of diagnosis, treatment, and follow-up of patients who developed complications.
\end{abstract}

Methods: A total of 10 patients who underwent a rectosigmoidoscopy or colonoscopy in our endoscopy unit between January 2007 and January 2017 were retrospectively evaluated. The demographic characteristics of the patients, endoscopy findings, diagnosis of complications, time of diagnosis, and the treatment and follow-up results were analyzed.

Results: Of the 10 patients who developed complications, 6 were female and 4 were male. The mean age was 63.9 years (min-max: $48-83$ years). One patient had a splenic injury, another patient had postpolypectomy bleeding, and 8 patients had an iatrogenic colon perforation. Complications occurred in 9 patients during a diagnostic endoscopic procedure, while I complication occurred during a therapeutic endoscopic procedure. One elderly patient developed a perforation and as a result of a delayed diagnosis, mortality was seen due to postoperative sepsis.

Conclusion: Complications due to colonoscopic procedures can present with a varying clinical picture. Being aware of the complications and risk factors is of extreme importance for early diagnosis and the necessary intervention in these patients.

\section{INTRODUCTION}

Colonoscopy is an invasive, but effective procedure frequently used for diagnostic and therapeutic purposes. Transient gastrointestinal symptoms (pain, distension, etc.), are common side effects, but rarely, serious complications or mortality may develop. ${ }^{[l]}$ Colonic perforation, bleeding, or splenic injuries occurring during a colonoscopic procedure are serious complications and may threaten the patient's life. One study reported a rate of serious complications of $0.28 \% .{ }^{[2]}$ The postpolypectomy bleeding and perforation rates were reported as $0.16 \%$ to $1.48 \%$ and $0.02 \%$ to $0.1 \%$, respectively. ${ }^{[2]}$ The rate of life-threatening splenic injuries is much lower than presumed to be $(0.0005-0.017 \%) .{ }^{[3]}$
The mortality rate related to a colonoscopic examination has been reported to be no higher than $0.03 \%^{[3-5]}$

The objective of this study was to determine the complication rate of colonoscopy/rectosigmoidoscopy procedures performed, the approach to complications, and the mortality rate related to complications.

\section{MATERIAL AND METHODS}

Patients who underwent a colorectal system endoscopy in the endoscopy unit between January I, 2007 and January I, 2017 were retrospectively investigated using the hospital central information processing system. Approval of the ethics committee was obtained for the study (2017- 
39). The procedures were performed by certified general surgeons who perform colorectal surgery or by gastroenterology surgeons. The number of diagnostic and interventional colonoscopy/rectosigmoidoscopy procedures performed in the endoscopy unit within a period of 10 years was determined. The demographic characteristics of the patients, the type of complication, date of diagnosis, length of time before the procedure, type of intervention performed, and details of follow-up were recorded. All patients aged more than 18 years who underwent colonoscopy/rectosigmoidoscopy in the endoscopy unit of the hospital who developed complications were included in the study. Patients who developed complications as a result of a colonoscopy/rectosigmoidoscopy procedure performed at an external endoscopy center and who were referred to us for treatment were excluded from the study.

Descriptive statistical methods (mean, SD, minimum, median, maximum) were used to define continuous variables.

\section{Endoscopic procedure}

Mechanical bowel cleansing was performed in all of the patients who underwent a colonoscopic examination with Sennoside A+B calcium (X-M Diet solution $0.50 \mathrm{~g} / 250$ $\mathrm{mL}$; Yenişehir Laboratuvarı Ticaret ve Sanayi Ltd. Şti., Ankara, Turkey) at an average dose of $2 \mathrm{mg} / \mathrm{kg}$, dibasic sodium phosphate+2.4 g monobasic sodium phosphate (Fleet Fosfo soda $45 \mathrm{~mL}$; Kozmed Farmosötik Ürünler Ltd. Şti., Ankara, Turkey) at an average dose of $0.90 \mathrm{~g} /$ $\mathrm{kg}$, or sodium dihydrogen phosphate+disodium hydrogen phosphate (B.T. Enema $210 \mathrm{~mL}$ solution; Yenişehir Laboratuvarı Ticaret ve Sanayi Ltd. Şti., Ankara, Turkey), or dibasic sodium phosphate+monobasic sodium phosphate (Fleet Enema 133 mL; Kozmed Farmosötik Ürünler Ltd. Şti., Ankara, Turkey). In the cases of a flexible rectosigmoidoscopic examination, either mechanical bowel cleansing or a rectal enema was performed. The colonoscopic examinations were realized using the VP-4450HD video colonoscope (Fujifilm Holdings Corp., Tokyo, Japan), the EPX-2200 video colonosocope (Fujifilm Holdings Corp., Tokyo, Japan) or the Evis Exera II CV-I80 video colonoscope (Olympus Corp., Tokyo, Japan). Patients who had a history of anticoagulant use consulted with a specialist. If possible, anticoagulants were discontinued and replaced with a low-molecular-weight anticoagulant 5 days before the endoscopic procedure. Before the procedure, all of the patients provided written informed consent.

\section{RESULTS}

Over a period of 10 years, a total of 12,800 colorectal system endoscopy procedures were performed: 9100 colonoscopies and 3700 rectosigmoidoscopies. Postprocedural complications developed in a total of 10 patients (women: $n=6$, men: $n=4$ ) (Fig. I). The median age of the patients

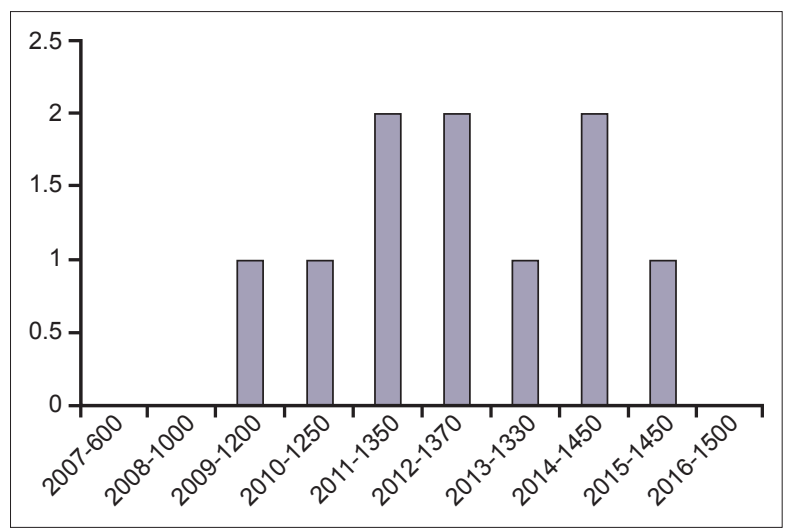

Figure 1. The annual number of colonoscopies and the distribution of complications.

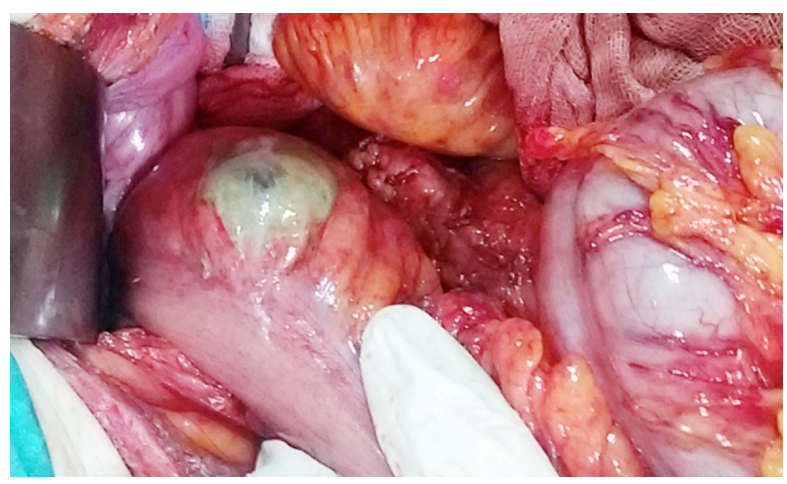

Figure 2. An iatrogenic sigmoid colon injury that occurred during a diagnostic colonoscopy procedure.

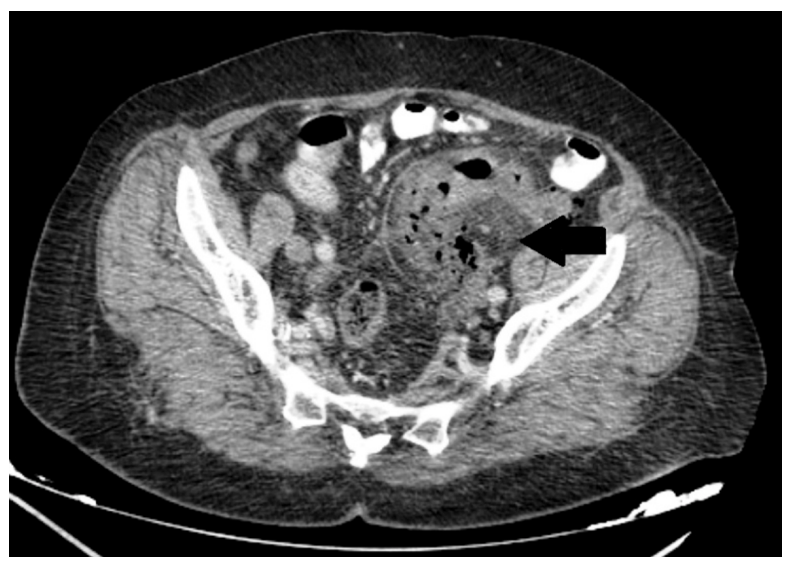

Figure 3. A computed tomography image of an iatrogenic colonic perforation that occurred during a colonoscopy.

was 63.9 years (min-max: 48-83 years). Splenic injury developed in I patient, postpolypectomy bleeding in I, and iatrogenic colonic perforation was observed in 8 patients (Fig. 2). In I case, the complication developed during a therapeutic endoscopic procedure, while in the remaining 9 , the procedure was diagnostic. latrogenic colonic perforation developed in a total of 6 patients, and 2 patients were hospitalized and medically followed up with the diagnosis of iatrogenic colonic perforation (Table I). Follow-up was 
Table I. Demographic features and diagnostic and follow-up details of patients who developed complications during a colonoscopy or rectosigmoidoscopy

\begin{tabular}{|c|c|c|c|c|c|c|}
\hline $\begin{array}{c}\text { Age } \\
\text { (years) }\end{array}$ & Gender & Localization & Diagnosis & $\begin{array}{l}\text { Time to diagnosis, } \\
\text { and if available, } \\
\text { operative time }\end{array}$ & Treatment & Outcome \\
\hline 67 & Female & Sigmoid colon & $\begin{array}{c}\text { Perforation-computed } \\
\text { tomography }\end{array}$ & $<12$ hours & Follow-up & Recovery \\
\hline 48 & Female & $\begin{array}{c}\text { Rectum } \\
\text { (polypectomy) }\end{array}$ & $\begin{array}{l}\text { Lower gastrointestinal } \\
\text { bleeding-digital rectal } \\
\text { examination }\end{array}$ & $<12$ hours & Follow-up & Recovery \\
\hline 53 & Female & Splenic flexure & $\begin{array}{c}\text { Splenic injury- } \\
\text { computed tomography }\end{array}$ & $\begin{array}{l}>12 \text { hours } \\
\text { (48 hours) }\end{array}$ & Splenectomy & Recovery \\
\hline 76 & Female & Sigmoid colon & $\begin{array}{c}\text { Perforation- computed } \\
\text { tomography }\end{array}$ & $\begin{array}{l}>12 \text { hours } \\
\text { (48 hours) }\end{array}$ & $\begin{array}{l}\text { Hartmann } \\
\text { procedure }\end{array}$ & $\begin{array}{c}\text { Death on } \\
4^{\text {th }} \text { day (sepsis) }\end{array}$ \\
\hline 83 & Male & Sigmoid colon & $\begin{array}{l}\text { Perforation- during } \\
\text { colonoscopy }\end{array}$ & $\begin{array}{l}<12 \text { hours } \\
\text { ( } 1 \text { hour) }\end{array}$ & Primary repair & Recovery \\
\hline 63 & $\begin{array}{l}\text { Male } \\
\text { colon }\end{array}$ & Rectosigmoid & $\begin{array}{l}\text { Perforation- during } \\
\text { colonoscopy }\end{array}$ & $<12$ hours & Follow-up & Recovery \\
\hline 68 & Female & Sigmoid colon & $\begin{array}{l}\text { Perforation- during } \\
\text { colonoscopy }\end{array}$ & $\begin{array}{l}<12 \text { hours } \\
\text { ( } 2 \text { hours) }\end{array}$ & Primary repair & Recovery \\
\hline 59 & Female & Sigmoid colon & $\begin{array}{l}\text { Perforation- during } \\
\text { colonoscopy }\end{array}$ & $\begin{array}{l}<12 \text { hours } \\
\text { ( } 2 \text { hours) }\end{array}$ & Primary repair & Recovery \\
\hline 58 & Male & Sigmoid colon & $\begin{array}{l}\text { Perforation- during } \\
\text { colonoscopy }\end{array}$ & $\begin{array}{l}<12 \text { hours } \\
\text { ( } 1 \text { hour) }\end{array}$ & Primary repair & Recovery \\
\hline 64 & Male & Sigmoid colon & $\begin{array}{l}\text { Perforation- during } \\
\text { colonoscopy }\end{array}$ & $\begin{array}{l}<12 \text { hours } \\
\text { (I hour) }\end{array}$ & Primary repair & Recovery \\
\hline
\end{tabular}

performed using abdominal examination, laboratory tests, and contrast-enhanced abdominal computed tomography (CT) (Fig. 3). The iatrogenic colonic perforation was noted in 7 patients during the endoscopic examination, while in I patient it went unnoticed during the examination. The patient presented at the emergency unit 48 hours after the procedure with the complaint of abdominal pain, and following a physical examination and radiological assessment, the patient was diagnosed with an iatrogenic colonic perforation. Five patients underwent a laparotomy shortly after the procedure, and in I case it was delayed. The rate of iatrogenic colonic perforation and splenic injury/bleeding in all of these procedures was $0.06 \%$ and $0.007 \%$, respectively. No morbidity or mortality was seen in the patients who developed iatrogenic colonic perforation and underwent a prompt laparotomy. Sepsis and mortality due to a delayed laparotomy was seen in I patient.

\section{DISCUSSION}

Awareness of potential complications and their causes is important to decrease the risk of occurrence. An experi- enced endoscopist, thorough diagnostic procedures, and a younger patient population decrease the complication rate. On the other hand, an inexperienced endoscopist, therapeutic procedures (biopsy, dilatation, etc.), advanced age, female gender, obesity, comorbid diseases, anticoagulant use, and previous abdominal surgery have been reported to increase the risk of complications. ${ }^{[3-8]}$ The general consensus is that performing 100 diagnostic and 25 interventional colonoscopic procedures are indicators of experience, and the incidence of complications will decrease with more experience. ${ }^{[9]}$ In a multicenter study performed by Teoh et al., ${ }^{[10]}$ it was reported that significantly fewer perforations occurred during a therapeutic colonoscopy when compared with diagnostic colonoscopy procedures. Gender was not found to be a risk factor for iatrogenic colonic perforation in some studies. ${ }^{\left[{ }^{\prime \prime}\right]}$ In our research, the endoscopic procedures were performed by expert endoscopists, and the median age of the patients who developed complications was 63.9 years. No gender difference was detected in the rate of patients who developed complications. The number of complications that occurred during a diagnostic colonoscopy was 9-times higher 
than the number seen during a therapeutic colonoscopy. The larger number of complications observed during a diagnostic colonoscopy was attributed to the advanced age of some patients, the presence of sigmoid colon diverticula, and previous abdominal surgery.

In high-risk patients, as an alternative to colonoscopic procedures to detect colonic pathology, noninvasive techniques such as colonography using a double-contrast technique, CT colonography, and a virtual colonoscopy should be considered. ${ }^{[12]}$

In the literature, the mortality rate associated with a colonoscopic examination ranges between $0.01 \%$ and $0.02 \%$ in the general patient population and $13 \%$ to $37.5 \%$ in patients who develop a perforation. ${ }^{[11,13]}$ In our study group, the mortality rate was $0.007 \%$ in the general population and $12.5 \%$ in the group that developed a perforation. After the procedure, 2 patients were admitted and followed up with a suspected iatrogenic colonic perforation. During the follow-up of both of these patients, an increase in attenuation, which suggests the presence of inflammation, was observed on abdominal CT images around the sigmoid colon, as well as free air in the abdomen. In I patient, multiple diverticula were detected in the sigmoid colon and the descending colon. Clinical evaluation did not reveal any evidence of peritonitis. The laboratory (hemogram, C-reactive protein) and abdominal CT findings were not abnormal, and the patient was discharged with prescription for medical treatment. Advanced age and delayed awareness of a perforation at a later stage may have been risk factors for mortality secondary to iatrogenic colonic perforation in I of our patients.

Wherry et al. ${ }^{[14]}$ first described a splenic injury that developed as a result of a colonoscopic procedure in 1974. [14] Although the mechanism has not been fully clarified, excess traction on the splenocolic ligament or direct trauma during the procedure may cause a subcapsular laceration of the spleen. ${ }^{[15,16]}$ Predisposing factors may include splenomegaly, inflammatory bowel diseases, coagulopathies, anticoagulant use, and excess looping. ${ }^{[17,18]}$ External compression during the procedure has also been reported as a risk factor. ${ }^{[16]}$ In our study, a splenic injury that occurred during a colonoscopic procedure was thought to be related to excess traction on the spleen as a result of the sharp angulation in the splenic flexure. The injury was not noticed during the procedure. Two days after the procedure, the patient presented at the emergency service with the complaint of left posterosuperior quadrant abdominal pain. An abdominal CT image revealed a grade 3 splenic injury. As the patient was hemodynamically unstable, a splenectomy was performed.

Following a colonoscopic polypectomy, rarely, colonoscopy-related bleeding episodes are seen, most frequently during excision of pedunculated polyps larger than
$2 \mathrm{~cm}$ in size. ${ }^{[19]}$ Postpolypectomy bleeding has been detected within the first 24 hours after the procedure in $98 \%$ of cases. ${ }^{[20]}$ In $95 \%$ of cases, postpolypectomy bleeding can be prevented endoscopically with an adrenalin injection to the base of the resected polyp, hemoclip application, and cauterization or band ligation at the base. ${ }^{[21,22]}$ In our study, a nearly $2-\mathrm{cm}$ pedunculated polyp was cauterized and excised with a snare and the patient was discharged after the procedure. The patient presented at the emergency unit with complaints of lower gastrointestinal system bleeding and was treated on an inpatient basis. The patient had a low hematocrit level (23.6\%) and was given 2 units of erythrocytes and 2 units of fresh frozen plasma. There was no bleeding and once the clinical and laboratory findings were stable, the patient was discharged.

The retrospective design of our study, the lack of any information on the indications prompting an endoscopic procedure other than demographic data, and the inability to access data that might have explained complications or to identify patients who applied to another healthcare institution are limitations of our study.

In conclusion, though colonoscopic procedures have a low complication rate, when they develop, they can cause serious morbidity and mortality. Early diagnosis of complications may be life-saving. Therefore, patients with complication risks and those with suspected complications should be monitored closely.

This study was described in a verbal presentation at the $16^{\text {th }}$ Turkish Colon and Rectum Surgery Congress held in Antalya, Turkey, May 16-20, 2017.

Ethics Committee Approval

Ethics committee approved.

Informed Consent

Retrospective study.

Peer-review

Internally peer-reviewed.

Authorship Contributions

Concept: H.H.A.; Design: H.H.A.; Data collection \&/ or processing: M.G., M.O.G.; Analysis and/or interpretation: E.G., E.Ö.; Literature search: H.H.A., E.G.; Writing: H.H.A.; Critical review: M.A., T.M., E.Ö.

Conflict of Interest

None declared.

\section{REFERENCES}

1. Ko CW, Dominitz JA. Complications of colonoscopy: magnitude and management. Gastrointest Endosc Clin N Am 2010;20:659-71.

2. Whitlock EP, Lin JS, Liles E, Beil TL, Fu R. Screening for colorectal cancer: a targeted, updated systematic review for the U.S. Preventive Services Task Force. Ann Int Med 2008;149:638-58. [CrossRef] 
3. Viiala $\mathrm{CH}$, Zimmerman M, Cullen DJ, Hoffman NE. Complication rates of colonoscopy in an Australian teaching hospital environment. Intern Med J 2003;33:355-9. [CrossRef]

4. Lorenzo-Zúñiga V, Moreno de Vega V, Doménech E, Mañosa M, Planas R, Boix J. Endoscopist experience as a risk factor for colonoscopic complications. Colorectal Dis 2010;12:273-7. [CrossRef]

5. Rabeneck L, Paszat LF, Hilsden RJ, Saskin R, Leddin D, Grunfeld E, et al. Bleeding and perforation after outpatient colonoscopy and their risk factors in usual clinical practice.Gastroenterology 2008;135:1899-906. [CrossRef]

6. Miller AM, McGill D, Bassett ML. Anticoagulant therapy, antiplatelet agents and gastrointestinal endoscopy. J Gastroenterol Hepatol 1999;14:109-13. [CrossRef]

7. Dobbins C, Defontgalland D, Duthie G, Wattchow DA. The relationship of obesity to the complications of diverticular disease. Colorectal Dis 2006;8:37-40. [CrossRef]

8. Ko CW, Riffle S, Shapiro JA, Saunders MD, Lee SD, Tung BY, et al. Incidence of minor complications and time lost from normal activities after screening or surveillance colonoscopy. Gastrointest Endosc 2007;65:648-56. [CrossRef]

9. Vennes JA, Ament M, Boyce HW Jr, Cotton PB, Jensen DM, Ravich WJ et al. Principles of training in gastrointestinal endoscopy. American Society for Gastrointestinal Endoscopy. Standards of Training Committees. 1989-1990. Gastrointest Endosc 1992;38:743-6.

10. Teoh AY, Poon CM, Lee JF, Leong HT, Ng SS, Sung JJ, et al. Outcomes and predictors of mortality and stoma formation in surgical management of colonoscopic perforations: a multicenter review. Arch Surg 2009;144:9-13. [CrossRef]

11. Baş G, Okan İ, Erözgen F, Eryılmaz R, Alimoğlu O, Işık A, et al. Management of Iatrogenic Colonic Perforations Related to Colonoscopic Examination. Turk J Colorectal Dis 2009;19:122-8.

12. Nadir I, Türkay C, Kasapoğlu B, Bayram Y, Aydoğan D. Is colono- scopic screening necessary in the elderly population? Turk J Acad Gastroenterol 2011;10:28-31.

13. Lohsiriwat V, Sujarittanakarn S, Akaraviputh T, Lertakyamanee N, Lohsiriwat D, Kachinthorn U. Colonoscopic perforation: A report from World Gastroenterology Organization endoscopy training center in Thailand. World J Gastroenterol 2008;14:6722-5. [CrossRef]

14. Wherry DC, Zehner H Jr. Colonoscopy-fiberoptic endoscopic approach to the colon and polypectomy. Med. Ann. Dist 1974;43:189_ 92.

15. Espinal EA, Hoak T, Porter JA, Slezak FA. Splenic rupture from colonoscopy. A report of two cases and review of the literature. Surg Endosc 1997;11:71-3. [CrossRef]

16. Janes SE, Cowan IA, Dijkstra B. A life threatening complication after colonoscopy. BMJ 2005;330:889-90. [CrossRef]

17. Rao KV, Beri GD, Sterling MJ, Salen G. Splenic injury as a complication of colonoscopy: a case series. Am J Gastroenterol 2009;104:1604-5. [CrossRef]

18. Fishback SJ, Pickhardt PJ, Bhalla S, Menias CO, Congdon RG, Macari M. Delayed presentation of splenic rupture following colonoscopy: clinical and CT findings. Emerg Radiol 2011;18:539-44. [CrossRef]

19. Rosen L, Bub DS, Reed JF 3rd, Nastasee SA. Hemorrhage following colonoscopic polypectomy. Dis Colon Rectum 1993;36:1126-31.

20. Frühmorgen P, Demling L. Complications of diagnostic and therapeutic colonoscopy in the Federal Republic of Germany. Results of an inquiry. Endoscopy 1979;11:146-50. [CrossRef]

21. Slivka A, Parsons W, Carr-Locke DL. Endoscopic band ligation for treatment of post-polypectomy hemorrhage. Gastrointest Endosc 1994;40:230-2. [CrossRef]

22. Katsinelos P, Chatzimavroudis G, Papaziogas B, Zavos C, Paroutoglou G, Pilpilidis I, et al. Endoclipping-assisted resection of large colorectal polyps. Surg Laparosc Endosc Percutan Tech 2008;18:1923. [CrossRef]

\section{Kolonoskopik Incelemeye Bağlı Gelișen Komplikasyonlar: Bir Cerrahi Kliniğinin 10 Yıllık Deneyimi}

Amaç: Kolonoskopi, kolorektal hastalıkların tanı ve tedavisinde rutin uygulanan bir prosedürdür. Bu çalışmada kolonoskopik incelemeye bağlı gelişen komplikasyonlar ve komplikasyon gelişen hastaların tanı, tedavi ve takip sonuçları değerlendirildi.

Gereç ve Yöntem: Ocak 2007-Ocak 2017 tarihleri arasında endoskopi ünitemizde rektosigmoidoskopi ve kolonoskopi incelemelerine bağlı komplikasyon gelişen 10 hasta geriye dönük değerlendirildi. Hastaların demografik özellikleri, endoskopi bulguları, komplikasyonları, tanı konma zamanı ile uygulanan tedavi ve takip sonuçları incelendi.

Bulgular: Toplam 10 hastada yapılan işlem sonrası komplikasyon gelişti. Hastaların altııı kadın, dördü erkek olup yaş ortalaması 63.9 (48-83 yaş) bulundu. Bir hastada splenik yaralanma, bir diğer hastada polipektomi sonrası kanama, sekiz hastada ise iatrojenik kolon perforasyonu gelişti. Terapötik endoskopik işlem sırasında bir hastada komplikasyon gelişirken diagnostik endoskopik işlem sırasında dokuz hastada komplikasyon gelişti. Perforasyon gelişen ve geç dönemde fark edilen yaşılı hastada ameliyat sonrası sepsis nedeniyle mortalite gelişmiştir.

Sonuç: Kolonoskopik işlemlere bağlı komplikasyonlar farklı şekillerde görülebilir. Ortaya çıkabilecek komplikasyonları ve risk faktörlerini bilmek, komplikasyon gelişen hastalarda erken tanı ve gerekli durumlarda erken müdahele çok önemlidir.

Anahtar Sözcükler: Kanama; kolonik polipler; kolonoskopi; splenektomi; yaralanmalar. 